\title{
EFEK ANTI JAMUR AIR RENDAMAN DAUN KELOR (Moringa oleifera) TERHADAP PERTUMBUHAN JAMUR Trichophyton mentagrophytes SECARA IN VITRO
}

\author{
Dewa Ayu Yuni Dewantari ${ }^{1}$., I Nyoman Jirna ${ }^{2}$., Ida Ayu Made Sri Arjani ${ }^{3}$.
}

\begin{abstract}
Background Moringa oleifera is a plant that all parts can be used for medicinal purposes. Roots, flowers, bark, stems, leaves and seeds of Moringa has antimicrobial properties. Compound content in leaves of moringa, such as tannin,steroid, alkaloid, saponins, and flavonoids .

Objective The purpose of this research was to know the different of Trichophyton mentagrophytes growth on various leaves of moringa (Moringa oleifera) concentration extract.

Methods This research uses a true experimental with post test only kontrol group design. The antifungal activity test use diffusion disk method, these were divided into four test group with concentration 25\%, 50\%, 75\%, 100\% and two kontrol group were positive kontrol (ketokonazole 2\%) and negatif kontrol (sterile distilled water).

The result of this study showed that the average diameter of inhibition zone of concentration $25 \%$ until $100 \%$ is $0 \mathrm{~mm}$. Statistic analysis was done by using Kolmogorof Smirnov test and Kruskal Wallis test. The test showed there was not a significant mean difference between group. All consentration haven't an effect on Trichophyton mentagrophytes growth inhibition zone diameter.

For next research with same topics using pure extract leaves of moringa was recommended.
\end{abstract}

Keywords: Inhibition zone, Moringa oleifera, Trichophyton mentagrophytes.

\section{PENDAHULUAN}

Pengobatan alternatif anti jamur dengan bahan alami dimaksudkan untuk mengurangi efek samping dari penggunaan bahan kimia dan resistensi terhadap obat akibat pemakaian dengan dosis tinggi dalam waktu singkat. Pengobatan dengan bahan alami untuk anti jamur ini juga dimaksudkan dapat sebagai pengobatan penunjang dan pengobatan terintegritas.
Kelor merupakan tanaman yang semua bagiannya dapat digunakan untuk tujuan pengobatan dan lainnya. Akar, bunga, kulit kayu, batang, daun dan biji kelor memiliki sifat antimikroba ${ }^{1}$. Dalam data hasil

1.,2.,3., Jurusan Analis Kesehatan Poltekkes Denpasar Korespondensi : Dewa Ayu Yuni Dewantari ${ }^{1}$, Jurusan Analis Kesehatan, Poltekes Denpasar, Jalan Sanitasi No. 1 Sidakarya, Denpasar-Bali 80224, Indonesia.

Telp. +62-361-710 527, Fax. +62-361-710 448

Email : meditoryjournal@gmail.com 
penelitian, disebutkan bahwa daun kelor memiliki kandungan metabolit sekunder berupa tanin, flavonoid, steroid, phlobatanins, glikosida dan terpene. Kandungan metabolit sekunder ini dapat mempengaruhi aktivitas anti jamur". Dalam "Journal of Natural Sciences Research" menyebutkan bahwa adanya tanin dapat menghambat pembentukan dinding sel jamur sehingga menyebabkan kematian $\operatorname{organisme}^{2}$. Hasil penelitian ekstrak petroleum eter dari daun dan kulit batang Moringa oleifera menimbulkan aktivitas anti jamur terhadap perkecambahan spora dan pertumbuhan miselia dari semua jamur patogen yang diujikan ${ }^{2}$.

Hasil Penelitian menyebutkan bahwa kelor mengandung konstituen fitokimia seperti alkaloid, flavonoid, karbohidrat, glikosida, protein, saponin, tanin dan terpenoid dalam ekstrak pelarut yang berbeda yaitu pelarut air dan etanol. Flavonoid meningkatkan efek Vitamin $\mathrm{C}$ dan berfungsi sebagai antioksidan, sehingga juga dikenal aktif biologis terhadap racun hati, tumor, virus dan mikroba lainnya. Kelor merupakan anti jamur yang baik terhadap beberapa organisme seperti Saccharomyces cerevisiae dan Candida tropicalis. Dari hasil penelitian ini, disebutkan bahwa kelor memiliki kandungan seperti flavonoid yang efektif sebagai zat anti jamur ${ }^{3}$.

Hasil penelitian ekstrak tumbuhan kelor dapat digunakan sebagai fungisida alami untuk mengendalikan jamur patogen dan dengan demikian mengurangi ketergantungan pada fungisida sintetik. Ekstrak daun kelor konsentrasi 50\% dapat menghambat perkecambahan spora dan berat miselia kering dari Fusarium oxysporum dan Fusarium solani sebesar $100 \%$, Alternaria solani sebesar 92,0\% dan 90,4\%. Ekstrak daun kelor pada konsentrasi $30 \%$ dan $40 \%$ paling efektif yang dapat menyebabkan pengurangan pertumbuhan dari miselia jamur berkisar antara 43,2\% sampai $70,0 \%{ }^{1}$.

Berdasarkan uraian diatas peneliti ingin melakukan uji daya hambat menggunakan air rendaman daun kelor (Moringa oleifera) terhadap pertumbuhan Trichophyton mentagrophytes. Pemilihan air rendaman daun kelor berdasarkan atas penelitian sebelumnya yang dilakukan oleh Penggunaan ekstrak air yang memiliki kemampuan untuk melarutkan zat fitokimia pada kelor, sehingga 
diharapkan dengan menggunakan air rendaman daun kelor dapat lebih mudah untuk diaplikasikan oleh masyarakat. Air rendaman daun kelor dibuat dengan empat konsentrasi yaitu 25\%, 50\%, $75 \%$, dan $100 \%$ sebagai anti jamur terhadap pertumbuhan Trichophyton mentagrophytes ${ }^{3}$.

\section{METODE PENELITIAN}

Penelitian ini merupakan penelitian True-experimental dengan Posstest only-kontrol design ${ }^{4}$. Pengujian aktivitas antijamur ini dilakukan dengan metode difusi dengan cara Kirby-Bauer Sampel penelitian berupa air rendaman daun kelor kosentrasi 25\%,50\%,75\% dan $100 \%$. Penelitian dibuat 3 kali pengulangan dan 2 kali replikasi sehingga didapat 24 sampel serta ditambah control positif dan negatif. Penelitian dilakukan di Laboratorium Mikrobiologi Fakultas Kedokteran Universitas Udayana.

Tahap penelitian dilakukan dengan penanaman Trichophyton mentagrophytes pada media SDA (Sabouraud Dextrose Agar). Kemudian masing-masing cakram disk yang mengandung air rendaman daun kelor konsentrasi 25, 50, 75, dan 100\%. Kontrol negatif (cakram disk mengandung aquadest steril) dan kontrol positif (cakram disk mengandung ketokonazol 2\%) juga ditempelkan pada permukaan media. Media SDA yang telah ditempeli cakram disk diinkubasi pada inkubator selama 4-5 hari.

Penghambatan pertumbuhan Trichophyton mentagrophytes ditandai dengan terbentuknya zona hambat/zona bening pada cakram disk. Pengukuran zona hambat menggunakan jangka sorong dan dinyatakan dalam satuan millimeter.

Data yang diperoleh dianalisis dengan uji statistik Kolmogorov Smirnov (KS) untuk menguji distribusi data, dilanjutkan dengan uji One Way Anova bila berdistribusi normal dan uji KW (Kruskal Wallis) bila tidak berdistribusi normal. Bila ada perbedaan dilanjutkan uji LSD (Least Significant Deference) atau uji Mann Whitney.

\section{HASIL DAN PEMBAHASAN}

Hasil penelitian yang diperoleh dari tiap replikasi dan pengulangan adalah tidak terbentuknya zona hambat (nilai zona hambat adalah $0 \mathrm{~mm}$ ), sedangkan untuk kontrol ketokonazol 2\% menghasilkan zona hambat dengan nilai rata-rata $14 \mathrm{~mm}$ yang menunjukkan uji yang dilakukan valid atau benar. 
Berdasarkan nilai keseluruhan zona tidak dilanjutkan dengan uji statistik. hambat sebesar $0 \mathrm{~mm}$ maka hasil ini

Tabel 1

Tabel hasil pengukuran zona hambat pertumbuhan Trichophyton mentagrophytes pada berbagai konsentrasi air rendaman daun kelor (Moringa oleifera).

\begin{tabular}{ccccccccc}
\hline \multirow{2}{*}{ Replikasi } & \multirow{2}{*}{ Pengulangan } & \multicolumn{3}{c}{ Zona hambat } & \multicolumn{3}{c}{ Kontrol } \\
\cline { 2 - 9 } & & $25 \%$ & $50 \%$ & $75 \%$ & $100 \%$ & $(+)$ & $(-)$ \\
\hline \multirow{2}{*}{ I } & 1 & 0 & 0 & 0 & 0 & 14 & 0 \\
\cline { 2 - 9 } & 2 & 0 & 0 & 0 & 0 & 14 & 0 \\
\hline \multirow{2}{*}{ II } & 3 & 0 & 0 & 0 & 0 & 13 & 0 \\
\cline { 2 - 9 } & 1 & 0 & 0 & 0 & 0 & 15 & 0 \\
\hline & 2 & 0 & 0 & 0 & 0 & 14 & 0 \\
\hline & 3 & 0 & 0 & 0 & 0 & 14 & 0 \\
\hline
\end{tabular}


Kandungan senyawa aktif dalam daun kelor seperti flavonoid dapat membentuk senyawa kompleks terhadap protein ekstraseluler yang mengganggu integritas membran dan dinding sel serta dapat mengganggu metabolisme sel mikroba dengan cara menghambat transport nutrisi. Tanin dapat menghambat pembentukan enzim C-14 demetilase yang berperan dalam sintesis ergosterol dan menghambat sintesis kitin pada dinding sel mikroba. Saponin dapat melisiskan membran sel mikroba dan menghambat DNA polymerase sehingga sintesis asam nukleat terganggu. Alkaloid dapat menghambat sintesis

asam nukleat dan mempengaruhi ergosterol pada jamur. Triterpenoid dan

steroid memiliki aktivitas antijamur dengan cara mempengaruhi permeabilitas membran sel yang akhirnya dapat menyebabkan membran sel lisis ${ }^{5}$.

Air rendaman daun kelor yang mengandungan metabolit sekunder seperti flavonoid, tanin, saponin dan triterpenoid, ternyata tidak membentuk zona hambat sebagai antijamur pada pertumbuhan Trichophyton mentagrophytes. Hal ini diduga karena jumlah dari kandungan senyawa metabolit sekunder yang telah disebutkan tidak cukup untuk menghambat pertumbuhan Trichophyton mentagrophytes. Dari Hasil penelitian tentang uji skrining fitokimia diperoleh kesimpulan bahwa uji ini hanya dapat membuktikan adanya suatu senyawa metabolit sekunder secara kualitatif, tidak secara kuantitatif, selain itu belum ada penelitian yang menyebutkan jumlah minimal suatu senyawa metabolit sekunder untuk menghambat

Trichophyton mentagrophytes, sehingga tidak dapat ditentukan apakah jumlah senyawa metabolit sekunder yang diperoleh dari air rendaman daun kelor tidak cukup untuk menghambat pertumbuhan Trichophyton mentagrophytes ${ }^{5}$. Beberapa senyawa seperti tanin umumnya dapat larut dalam air, namun kelarutan besar dan akan meningkat apabila dilarutkan dalam air panas ${ }^{6}$. Sehingga pada saat perendaman daun kelor yang menggunakan pelarut dalam suhu ruang tidak memperoleh kelarutan 
tanin yang optimal. Senyawa saponin memiliki kelarutan dalam pelarut organik yang dipengaruhi oleh suhu dan $\mathrm{Ph}^{6}$.

Menurut beberapa hasil penelitian menunjukkan kelarutan saponin maksimal adalah dalam etanol $60 \%$ serta kelarutan saponin dalam air akan meningkat pada suhu $30^{\circ} \mathrm{C}$. Hal ini menunjukkan bahwa senyawa saponin dalam proses perendaman daun kelor dengan pelarut air tidak melarutkan senyawa ini dengan optimal ${ }^{7}$.

Ekstrak daun kelor kemungkinan lebih berpengaruh untuk menghambat pertumbuhan Trichophyton mentagrophytes ditinjau dari hasil penelitian yang menyebutkan ekstrak daun kelor lebih efektif menghambat jamur Trichophyton mentagrophytes daripada ekstrak dari kulit kayu kelor $^{8}$. Pelarut yang digunakan untuk melarutkan harus memiliki sifat kepolaritasan yang sama dengan senyawa yang akan ditarik. Etanol dapat menarik senyawa metabolit sekunder dalam daun dalam jumlah hampir sama jika dibandingkan pelarut lain, namun etanol dapat mengoptimalkan penarikan beberapa senyawa dengan berat molekul rendah seperti saponin dan flavonoid ${ }^{9}$.

Menurut hasil penelitian disebutkan bahwa ekstrak daun kelor dengan pelarut etanol menghasilkan daya hambat yang lebih baik dibandingkan ekstrak daun kelor dengan pelarut air dalam penghambatan mikroba, sehingga ekstraksi dengan pelarut etanol kemungkinan lebih efektif sebagai anti jamur dikarenakan semua senyawa yang diharapkan pada daun kelor dapat terpisah dengan baik ${ }^{10}$.

Pada ekstraksi juga dilakukan proses penguapan pelarut, sehingga pada proses ini dapat meminimalisasi zat pengotor/zat yang tidak diharapkan yang ikut terlarut dalam pelarut. Pada air rendaman daun kelor diduga kandungan metabolit yang diperlukan untuk menghambat pertumbuhan Trichophyton mentagrophytes tidak terlarut secara optimal dikarenakan ada zat lain dalam daun yang juga larut dalam air sehingga menjadi pengotor pada pelarut. Pada hasil penelitian disebutkan senyawa fenolik dan flavonoid umumnya mudah larut dalam air karena sering kali 
berikatan dengan gula sebagai glikosida $^{11}$, untuk meningkatkan keefektifan memperoleh zat yang diinginkan, umumnya menggunakan campuran bahan pelarut yang berlainan, khususnya campuran etanol dan air. Etanol 70\% sangat efektif dalam menghasilkan jumlah bahan aktif yang optimal, dimana bahan pengganggu hanya skala kecil yang turut ke dalam cairan pengekstraksi ${ }^{12}$

\section{SIMPULAN DAN SARAN}

Simpulan

Diameter zona hambat pertumbuhan Trichophyton mentagrophytes pada air rendaman daun kelor konsentrasi $25 \%, 50 \%$, $75 \%$, dan $100 \%$ adalah $0 \mathrm{~mm}$ dan tidak ada perbedaan zona hambat air rendaman daun kelor (Moringa oleifera) terhadap pertumbuhan Trichophyton mentagrophytes secara in vitro.

Saran.

Bagi peneliti selanjutnya sebaiknya untuk melakukan metode ekstraksi dengan pelarut lain seperti etanol kemudian di uji kemampuan atau daya hambat terhadap
Trichophyton mentagrophytes atau jamur lain yang pathogen secara in vitro.

\section{DAFTAR PUSTAKA}

1. Riad, S.R., Mohamedy, E., and Abdalla, A.M., Evaluation of antifungal activity of Moringa oleifera extracts as natural fungicide against some plant pathogenic fungi In-vitro, Journal of Agricultural Technology, 10 (4) : 963-982, 2014.

2. Nweke, F., Antifungal Activity of Petroluem Ether Extracts of Moringa oleifera Leaves and Stem Bark against Some Plant Pathogenic Fungi, Journal of Natural Sciences Research, 5 (8) : 1-5, 2015.

3. Patel, P., et.al., Phytochemical Analysis And Antifungal Activity Of Moringa oleifera, International Journal of Pharmacy and Pharmaceutical Sciences, 6 (5) : 144-147, 2014.

4. Sugiyono, Metode Penelitian Kuantitatif Kualitatif dan $R \& D$, Bandung: Alfabeta, 2011.

5. Kurniawan, D., Uji Aktivitas Antijamur Ekstrak Etanol Daun Kelor (Moringa oleifera Lamk.) 
Terhadap Candida Albicans

Secara In Vitro, Skripsi,

Pontianak : Fakultas Kedokteran

Universitas Tanjungpura, 2015,

6. Ismarani, Potensi Senyawa

Tannin Dalam Menunjang

Produksi. Jurnal Agribisnis Dan

Pengembangan Wilayah, 3(2) : 46-55, 2012.

7. Prasetyo, dkk., Pengaruh Rasio Biji Teh / Pelarut Air Dan Temperatur Pada Ekstraksi Saponin Biji Teh Secara Batch, Skripsi, Bandung : Jurusan Teknik Kimia Universitas Katolik Parahyangan Bandung, 2011.

8. Nugraha, A., Bioaktivitas Ekstrak Daun Kelor (Moringa oleifera) terhadap Eschericia Coli Penyebab Kolibasilosis Pada Babi, Tesis, Denpasar : Fakultas Kedokteran Hewan Universitas Udayana, 2013.

9. Agustine, R., Perbandingan Sensitivitas Dan Spesifisitas Pemeriksaan Sediaan Langsung Koh 2a\% Dengan Sentrifugasi Dan Tanpa Sentrifugasi Pada Tinea Kruris, Skripsi, Padang : Universitas Andalas, 2012.
10. Nugraha, A., Bioaktivitas Ekstrak

Daun Kelor (Moringa oleifera) terhadap Eschericia Coli Penyebab Kolibasilosis Pada Babi, Tesis, Denpasar : Fakultas Kedokteran Hewan Universitas Udayana, 2013.

11. Indraswari, A., Optimasi Pembuatan Ekstrak Daun Dewandaru (Eugenia Uniflora L.) Menggunakan Metode Maserasi Dengan Parameter Kadar Total Senyawa Fenolik Dan Flavonoid, Skripsi, Surakarta : Fakultas Farmasi Universitas Muhammadiyah Surakarta. 2008.

12. Setyowati, R. Aktivitas Dan Potensi Ekstrak Larut Air Batang Kayu Kuning (Arcangelisia Flava L. Merr) Terhadapkoloni Candida Albicans Atcc 10231 Dan Trichophyton Mentagrophytes Secara In Vitro, Skripsi, Yogyakarta : Universitas Gadjah Mada, 2013. 